\title{
Kontrol Kecepatan Motor BLDC Menggunakan Cuk Konverter
}

\author{
Thoriqul Huda, Mohamad Akbar Mukti, Dzulfiqar Julda, Achmad Handoko Andrensyah, \\ Belly Yan Dewantara, Iradiratu Diah P.K, Istiyo Winarno
}

Teknik Elektro, Fakultas Teknik dan Ilmu Kelautan, Universitas Hang Tuah, Surabaya

Jl. Arif Rahman Hakim 150 Surabaya, Kode Pos 60111, Jawa Timur, Indonesia

E-mail: hthoriqul@gmail.com

\begin{abstract}
ABSTRAK
Abstrak - Motor Brushless Direct Current (BLDC) merupakan motor DC tanpa penggunaan sikat sehingga efisiensi pemakaian lebih tinggi, dibantu dengan adanya konverter tegangan DC dapat dikontrol dan diubah untuk mencapai efisiensi. Sejatinya kecepatan motor DC berubah ubah dan tidak terkontrol sehingga mempengaruhi kinerja beban. Pada penelitian ini cuk konverter digunakan sebagai pengkontrol kecepatan motor BLDC. Cuk konverter dapat mengontrol kecepatan motor BLDC dengan mengatur tegangan output dari motor DC, Skema penelitian yang dilakukan disimulasikan ke dalam program PSIM dan perbandingan kinerja sistem tak terkontrol dengan sistem terkontrol. Dengan merancang cuk konverter terkontrol, dapat mengatur kecepatan motor DC secara otomatis dengan acuan kecepatan referensi yang telah ditetapkan pada berbagai variasi pembebanan. Sehingga kecepatan dapat dipertahankan meskipun dengan berbagai nilai pembebanan. Hasil dari penelirian menunjukan bahwa sistem terkontrol tidak terjadi overshoot karena dapat diredam oleh sistem PID sehingga tidak terjadi lonjakan kecepatan pada motor BLDC itu sendiri. Hal ini membuktikan bahwa Cuk Konverter dapat digunakan untuk mengontrol kecepatan motor dan menekan laju overshoot.
\end{abstract}

Kata kunci: Cuk Konverter, Motor BLDC, Kontrol kecepatan

\section{ABSTRACT}

\begin{abstract}
Brushless Direct Current (BLDC) motor is a DC motor without the use of a brush so that the efficiency of use is higher, assisted by the presence of a DC voltage converter that can be controlled and changed to achieve efficiency. In fact, the speed of a DC motor changes and is not controlled so that it affects load performance. In this research, the choke converter is used as a BLDC motor speed controller. Cuk converter can control the speed of the BLDC motor by adjusting the output voltage of the DC motor. The research scheme is simulated into the PSIM program and the comparison of the performance of the uncontrolled system with the controlled system. By designing a controlled converter, it can adjust the speed of the DC motor automatically with a reference speed reference that has been set for a variety of loading variations. So that the speed can be maintained even with various loading values. The results of the research show that the controlled system does not occur overshoot because it can be damped by the PID system so that there is no speed spike on the BLDC motor itself. This proves that the Cuk Converter can be used to control motor speed and reduce the overshoot rate.
\end{abstract}

Keywords: Cuk Converter, BLDC Motor, Speed Control

Copyright @ 2019 Universitas Muhammadiyah Jember.

\section{PENDAHULUAN}

Aplikasi motor BLDC sangat direkomendasikan dan sangat populer, karena tingginya tingkat efisiensi, perawatan yang mudah, dan juga kontrol kecepatan yang mudah. Hal ini terjadi karena motor BLDC tidak memiliki sikat dan komutator. Banyak penerapan aplikasi motor BLDC dikehidupan seharihari seperti pada mesin cuci, kipas, kulkas, dll. Untuk dapat mengkontrol kecepatan pada motor BLDC diperlukan DC - DC konverter, karena pada dasarnya pengendalian kecepatan motor sama dengan mengendalikan tegangan pada motor BLDC. DC-DC konverter berfungsi untuk mengkonversi tegangan masukan searah konstan menjadi tegangan keluaran searah yang dapat divariasikan berdasarkan perubahan duty cycle rangkaian kontrol. DC-DC konverter digunakan untuk mengubah sumber tegangan DC yang tetap menjadi tegangan DC yang variable yang mengatur kondisi on-off rangkaian $D C$ chopper 
melalui rangkaian kontrol PWM [1]. Penggunaan cuk konverter dapat mengontrol kecepatan motor BLDC dengan mengatur tegangan output dari motor DC yang sebelumnya sudah diubah dari tegangan input berupa tegangan AC, Skema penelitian yang dilakukan disimulasikan ke dalam program PSIM dan perbandingan sistem tak terkontrol dan sistem terkontrol menggunakan PI [2].

Sejatinya kecepatan motor DC tidak konstan karena tegangan output yang dihasilkan berubah - ubah, hal ini dapat mempengaruhi kenerja dari beban sehingga menghambat efisiensi beban, untuk itu diperlukan kontrol untuk menyesuaikan kecepatan dari motor BLDC dengan kebutuhan. Berdasarkan latar belakang yang diungkapkan di atas, maka akan dibuat suatu penelitian yakni mengontrol kecepatan dari motor BLDC dengan menggunakan cuk konverter, dan juga mengoptimalkan efisiensi kerja dari motor BLDC dengan menekan overshoot sampai ke titik 0 melalui redaman oleh sistem PID sehingga tidak terjadi lonjakan kecepatan pada motor BLDC itu sendiri.

\section{KAJIAN PUSTAKA}

\subsection{Motor Brushless DC}

Motor Brushless Direct Current (BLDC) adalah motor DC tanpa penggunaan sikat sehingga efisiensi pemakaian lebih tinggi. Unit motor DC brushless memiliki fitur berikut.

1. Memiliki efisiensi tinggi karena rotor magnet permanen digunakan dan kerugian sekunder kecil.

2. Inersia rotor dapat dikurangi, dan respons kecepatan tinggi diperoleh.

3. Dimungkinkan untuk berhemat motor karena sangat efisien.

4. Fluktuasi kecepatan dengan perubahan beban rendah.

Motor BLDC memiliki kelebihan dibandingkan dengan motor jenis lain, metode pengendalian motor BLDC jauh lebih rumit untuk kecepatan dan torsi yang konstan [3].

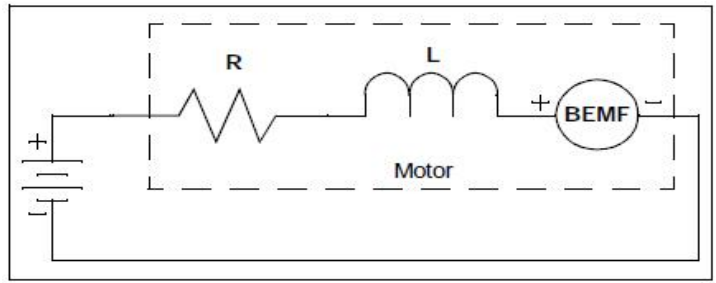

Gambar 1. Rangkaian Ekivalen BLDC

\subsection{Cuk Konverter}

Cuk konverter adalah konverter penyempurna dari konverter buck-boost. Berfungsi menaikkan dan menurunkan tegangan dan memiliki keluaran polaritas terbalik. Sumber tegangan cuk konverter merupakan arus searah (DC), dan masukan dari cuk konverter yaitu induktor (L1), sedangkan keluarannya terdapat induktor (L2), kapasitor digunakan untuk mentransfer tegangan (C1). Cuk konverter juga menggunakan kapasitor filter (C2), juga memiliki saklar dan diode, beban (resistif). Untuk mengurangi gelombang yang tidak beraturan masukan dari cuk konverter digunakan sebagai filter. Perbedaan yang sangat menonjol dengan konverter lainnya terjadi pada kapasitor yaitu kapasitor digunakan untuk mentrasnfer tegangan, sedangkan induktor pada konverter lainya digunakan untuk mentransfer tegangan. Kelebihan yang dimiliki pada sisi masukan dan keluaran memiliki arus yang kontinyu. Kelemahannya sendiri terdapat pada nilai reaktif pada komponen dan arus yang berada pada saklar sangat besar, untuk mentrasnfer tegangan membutuhkan dioda dan kapasitor.

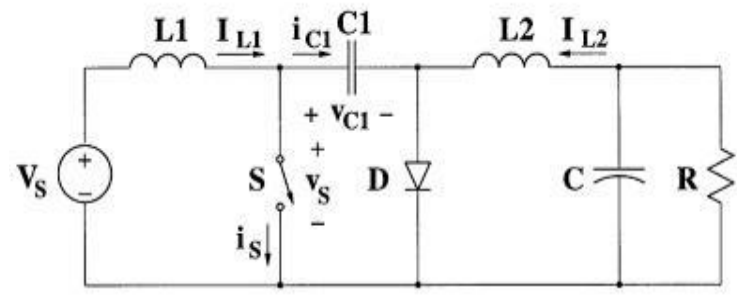

Gambar 2. Rangkaian cuk converter 
Dalam keadaan saklar on akan tertutup sehingga dilewati oleh arus, dioda tidak bekerja, dan kapasitor discharge oleh arus dari induktor. Ketika saklar off akan terbuka dioda mengaliri arus dari induktor. Dan kapasitor dialiri arus dari induktor [4][5].

\subsection{Powersim}

Powersim atau PSIM merupakan suatu produk simulasi yang ditujukan ke bidang elektronika daya (power electronics), dan dijadikan salah satu standar industri. Untuk keperluan di bidang pendidikan PSIM dijadikan sebuah rujukan perbandingan karana mempunyai tingkat akurasi dan ketepatan yang cukup tinggi ditambah fitur-fitur yang lengkap [6].

\subsection{Kontrol PI}

Sistem kontrol menggunakan metode PI sudah banyak digunakan. Sistem ini terdiri dari dua macam kontrol yaitu proporsional sebagai penguat mencapai set poin, kontrol integral sebagai mempercepat respon, dan kontrol. Kontrol-kontrol tersebut bertujuan mempercepat respon, menghilangkan offset, dan menghasilkan perubahan awal yang cepat sebagaimana yang diinginkan. [7][8][9].

\section{METODE PENELITIAN}

\subsection{Konfigurasi Sistem}

Dalam sistem kontrol kecepatan motor DC ada beberapa hal yang perlu disiapkan seperti penyearah, DC converter berupa cuk converter, dan motor BLDC yang akan digunakan. Pada sistem dijelaskan sumber daya berupa tegangan AC yang kemudian disearahkan menjadi tegangan DC, proses penyearahan ini dilakukan oleh penyearah dioda. Kemudian tegangan DC diatur sesuai kebutuhan menggunakan cuk konverter untuk menggerakan motor BLDC. Sebagai perbandingan sistem menggunakan 2 sistem, yaitu sistem tak terkontrol dan sistem terkontrol menggunkan PI.

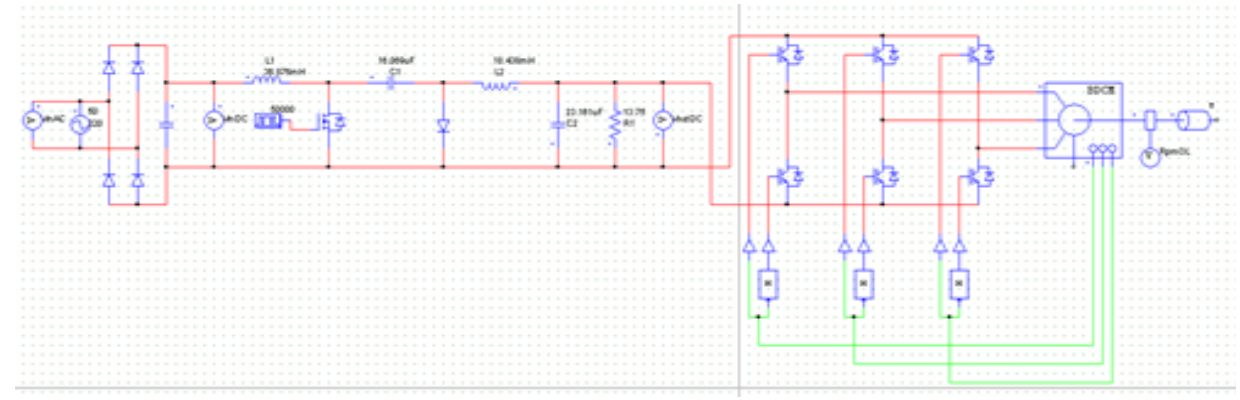

Gambar 3. Skema sistem rangkaian tak terkontrol

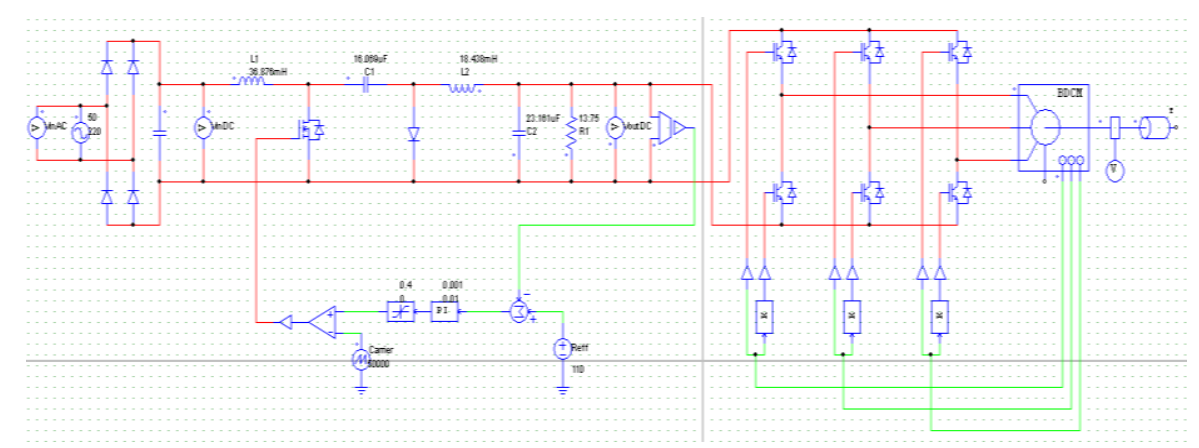

3.2. Motor BLDC

Gambar 4. Skema rangkaian terkontrol

Penelitian ini merupakan simulasi yang dilakukan dengan menggunakan software PSIM, Spesifikasi motor BLDC yang digunakan keluaran MOOG, seri BN42-53IP-03 dengan daya sebesar 874 watt. 
Tabel 1. Spesifikasi motor DC

\begin{tabular}{ll}
\hline Parameter & Nilai \\
\hline Rated power & $874 \mathrm{watt}$ \\
Rated speed & $2820 \mathrm{rpm}$ \\
Rated torque & $2.9588 \mathrm{Nm}$ \\
Resistance & $0,408 \mathrm{Ohm}$ \\
Inductance & $1.71 \mathrm{mH}$ \\
Torque constant $(\mathrm{Nm} / \mathrm{A})$ & 0,3269 \\
No. Of poles & 8 \\
Momen of Inersia & $0,4939 \times 10^{-3} \mathrm{Kg} \cdot \mathrm{m}^{2}$ \\
No-load speed & $2920 \mathrm{rpm}$ \\
No-load current & $0.7 \mathrm{~A}$ \\
Speed constant $(\mathrm{rpm} / \mathrm{V})$ & 29.239 \\
\hline
\end{tabular}

\subsection{Cuk Konverter}

Pada penelitian ini cuk konverter digunakan untuk mengkontrol kecepatan motor DC. Berikut ini adalah rating perancangan cuk konverter dalam mengendalikan kecepatan motor BLDC dengan beban yang berbeda. cuk konverter dengan tegangan AC satu fasa $220 \mathrm{~V}$ yang disearahkan oleh rangkaian penyearah yang dilengkapi dengan filter tegangan yaitu kapasitor yang nantinya menghasilkan tegangan DC 220V.

Tabel 2. Rating cuk converter

\begin{tabular}{ll}
\hline Parameter & Nilai \\
\hline Tegangan Input (Vs) & $220 \mathrm{~V}$ \\
Tegangan Output (Vo) & $110 \mathrm{~V}$ \\
Daya Output (P) & $875 \mathrm{~W}$ \\
Frekuensi switching (fs) & $50000 \mathrm{~Hz}$ \\
Faktor ripple ( $\lambda$ ) & 0.01 \\
Induktor 1 (L1) & $36.876 \mathrm{mH}$ \\
Induktor 2(L2) & $18.438 \mathrm{mH}$ \\
Kapasitor 1 (C1) & $16.069 \mathrm{uF}$ \\
Kapasitor 2 (C2) & $23.161 \mathrm{uF}$ \\
\hline
\end{tabular}

\subsubsection{Menentukan Duty Cyrcle}

Nilai dari dutycycle didapatkan setelah ditentukannya tegangan kerja input dan output, berdasarkan rumus nilai dutycycle dapat diperoleh:

$$
\begin{gathered}
\frac{V o}{V s}=-\frac{D}{1-D} \\
V_{o}=V_{s} \frac{D}{1-D} \\
110=220 \frac{D}{1-D} \\
110-110 D=220 D \\
110=220 D+110 D \\
\frac{110}{330}=D \\
0.3=D
\end{gathered}
$$




\subsubsection{Menentukan Nilai Resistor}

Berdasarkan daya keluaran yang diinginkan dan nilai tegangan keluaran, dapat ditentukan nilai beban atau resistornya dengan menghitung arus keluarannya terlebih dahulu.

$$
\begin{gathered}
I_{o}=\frac{P_{o}}{V_{o}} \\
I_{O}=\frac{875}{110}=7.954 \mathrm{~A} \approx 8 \mathrm{~A} \\
R=\frac{V_{O}}{I_{O}} \\
R=\frac{110}{8}=13.75 \Omega
\end{gathered}
$$

\subsubsection{Menentukan Nilai Induktor dan Kapasitor}

Setelah nilai-nilai tegangan masukan dan keluaran, daya, arus, dan beban diketahui, selanjutnya mencari nilai-nilai induktor dan kapasitor untuk merancang rangkaian cuk konverter.

- Nilai induktor 1

$$
\begin{gathered}
L_{1}=\frac{V_{s}^{2} \times V_{o}}{\lambda \times P \times f_{s} \times\left(V_{o}+V_{s}\right)} \\
L_{1}=\frac{220^{2} \times 110}{0.01 \times 875 \times 50000 \times(110+220)}=36.876 \mathrm{mH}
\end{gathered}
$$

- Nilai Induktor 2

$$
\begin{gathered}
L_{2}=\frac{V_{s} \times V_{o}^{2}}{\lambda \times P \times f_{s} \times\left(V_{o}+V_{s}\right)} \\
L_{2}=\frac{220 \times 110^{2}}{0.01 \times 875 \times 50000 \times(110+220)}=18.438 \mathrm{mH}
\end{gathered}
$$

- Nilai Kapasitor 1

$$
\begin{gathered}
C_{1}=\frac{P}{\lambda \times f_{s} \times\left(V_{o}+V_{s}\right)^{2}} \\
C_{1}=\frac{875}{0.01 \times 500000 \times(110+220)^{2}}=16.069 \mathrm{uF}
\end{gathered}
$$

- Nilai kapasitor 2

$$
\begin{gathered}
C_{2}=i \frac{1}{2 \times \pi \times f_{s} \times \lambda \times V_{o}} \\
C_{2}=8 \frac{1}{2 \times 3.14 \times 50000 \times 0.01 \times 110}=23.161 \mathrm{uF}
\end{gathered}
$$




\section{HASIL DAN PEMBAHASAN}

\subsection{Penyearah (Rectifier)}

Pada rangkaian ini diperlukan penyearah (rectifier) sebagai perubah tegangan $\mathrm{AC}$ menjadi tegangan DC yang berfungsi sebagai catudaya untuk rangkaian cuk konverter. Dengan menggunakan diode yang disusun sedimikian rupa sehingga menyearahkan tegangan AC menjadi tegangan DC yang dilengkapi dengan kapasitor sebagai filter tegangan untuk memperkecil besar ripple nya.

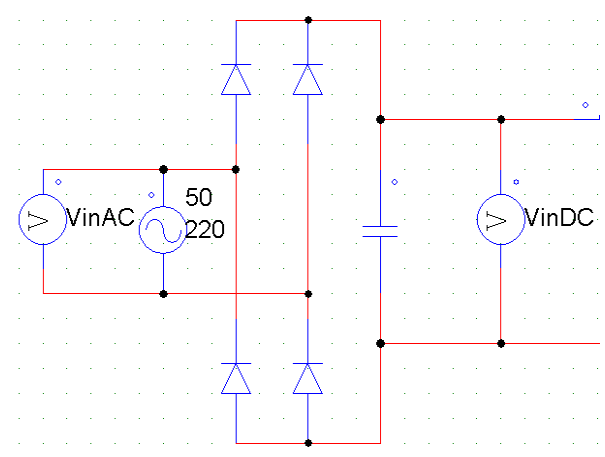

Gambar 5. Rangkaian rectifier

\subsection{Cuk Konverter}

Cuk konveter merupakan sebuah konverter DC-DC yang berfungsi menaik turunkan tegangan, yang prinsip kerjanya sama dengan buck-boost. Dalam simulasi ini menggunakan rancangan cuk konverter tak terkontrol dan rangkaian cuk converter terkontrol.

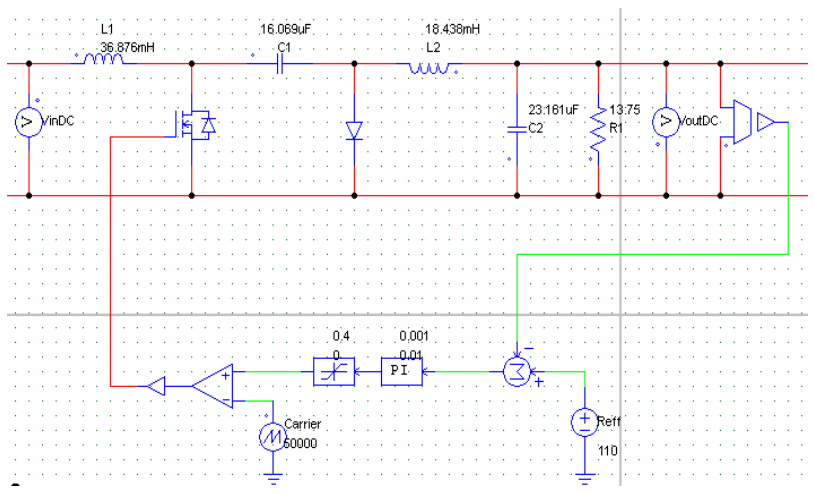

Gambar 6. Rangkaian cuk converter terkontrol PI

Untuk rangkaian cuk konverter terkontrol menggunakan tegangan keluaran sebagai pembanding dengan tegangan referensi untuk dikelola oleh sistem kontrol PI untuk mendapatkan tegangan keluaran seperti yang diinginkan dan stabil. Pada rangkaian simulasi ini cuk konverter digunakan menurunkan tegangan masukan untuk menyuplai tegangan pada motor Brushless DC (BLDC) yang mana berfungsi sebagai pengotrol kecepatan motor saat tidak berbeban dan berbeban.

\subsection{Hasil Simulasi}

Untuk simulasi menggunakan software PSIM (power simulator) untuk mengetahui sistem yang dirancang sesuai dengan yang diinginkan. Simulasi ini membandingkan kecepatan motor saat menggunakan sistem tak terkontrol dan terkontrol dengan motor berbeban dan tidak berbeban. Untuk beban motor menggunakan beban $2.5 \mathrm{Nm}$ dan $4.5 \mathrm{Nm}$. Dengan tegangan masukan $220 \mathrm{~V}$ dan tegangan keluaran $110 \mathrm{~V}$. 


\subsubsection{Simulasi Kecepatan Motor BLDC Tanpa Beban}

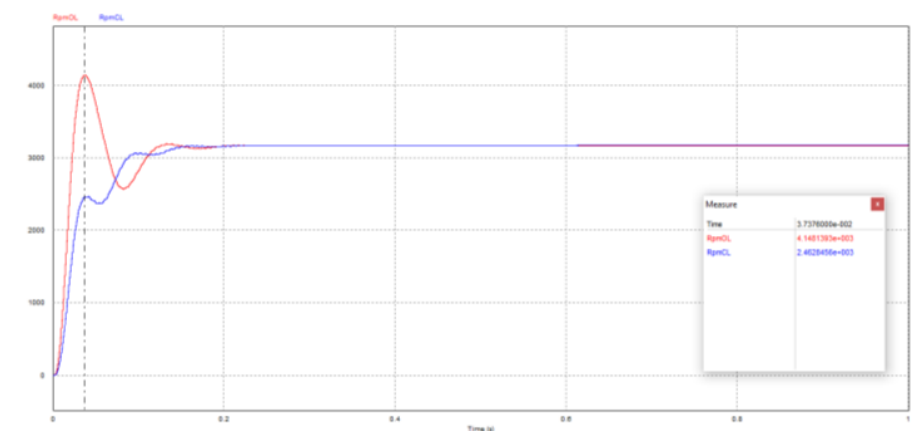

Gambar 7. Grafik kecepatan motor DC tanpa beban

Pada gambar grafik diatas merupakan hasil kecepatan motor BLDC dengan mengambil parameter waktu 1 detik pada sistem tak terkontrol (merah) dan terkontrol (biru), terlihat pada sistem tak terkontrol terjadi overshoot sampai $4148.1 \mathrm{Rpm}$, untuk kecepatan pada waktu konstan pada sistem tak terkontrol mendapatkan $3167.46 \mathrm{Rpm}$ dan pada terkontrol mendapatkan 3168.95 Rpm

Tabel 3. Nilai kecepatan motor BLDC tanpa beban

\begin{tabular}{ccc}
\hline Tanpa Beban & Kecepatan & Overshoot \\
\hline Tak terkontrol & $3167.46 \mathrm{Rpm}$ & $4148.1 \mathrm{Rpm}$ \\
Terkontrol & $3168.95 \mathrm{Rpm}$ & - \\
\hline
\end{tabular}

\subsubsection{Simulasi Kecepatan Motor BLDC Dengan Beban 2.5 Nm}

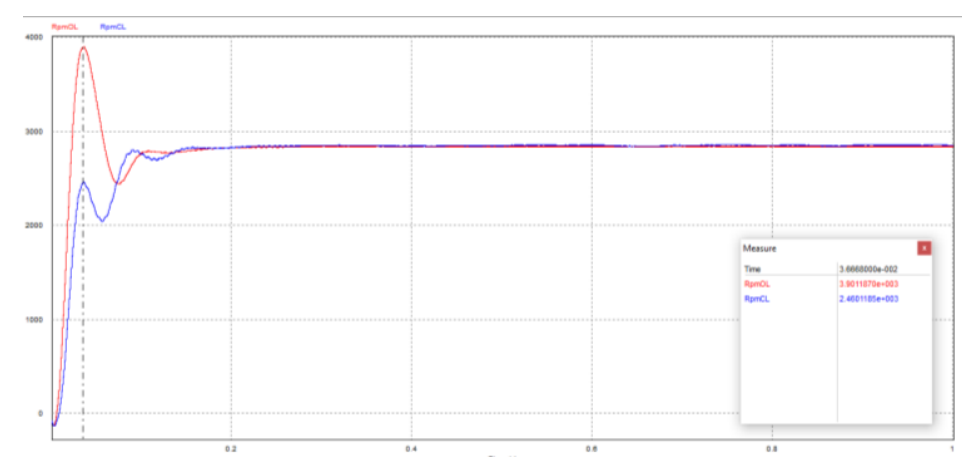

Gambar 8. Grafik kecepatan motor BLDC dibebani 2.5 Nm

Pada gambar grafik diatas merupakan hasil kecepatan motor BLDC dengan mengambil parameter waktu 1 detik pada sistem tak terkontrol (merah) dan terkontrol (biru), terlihat pada sistem tak terkontrol terjadi overshoot sampai $3901.2 \mathrm{Rpm}$, untuk kecepatan pada waktu konstan pada sistem tak terkontrol mendapatkan $2838.33 \mathrm{Rpm}$ dan pada terkontrol mendapatkan $2847.14 \mathrm{Rpm}$

Tabel 4. Nilai kecepatan motor BLDC dibebani $2.5 \mathrm{Nm}$

\begin{tabular}{ccl}
\hline Tanpa Beban & \multicolumn{1}{c}{ Kecepatan } & \multicolumn{1}{c}{ Overshoot } \\
\hline Tak terkontrol & $2838.33 \mathrm{Rpm}$ & $3901.2 \mathrm{Rpm}$ \\
Terkontrol & $2847.14 \mathrm{Rpm}$ & - \\
\hline
\end{tabular}




\subsubsection{Simulasi Kecepatan Motor BLDC Dengan Beban 4.5 Nm}

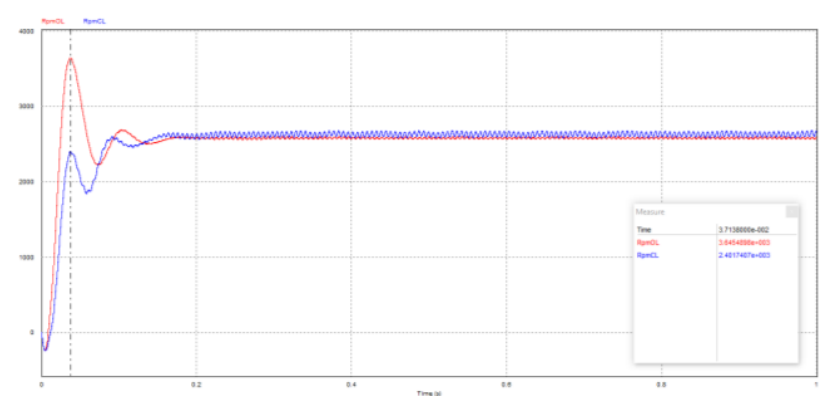

Gambar 9. Grafik kecepatan motor BLDC dibebani 4.5Nm

Pada gambar grafik diatas merupakan hasil kecepatan motor BLDC dengan mengambil parameter waktu 1 detik pada sistem tak terkontrol (biru) dan terkontrol (merah), terlihat pada sistem tak terkontrol terjadi overshoot sampai $3645.4 \mathrm{Rpm}$, untuk kecepatan pada waktu konstan pada sistem tak terkontrol mendapatkan 2579.9 Rpm dan pada terkontrol mendapatkan $2628.3 \mathrm{Rpm}$.

Tabel 5. Nilai kecepatan motor BLDC dibebani 4.5 Nm

\begin{tabular}{ccc}
\hline Tanpa Beban & \multicolumn{1}{c}{ Kecepatan } & \multicolumn{1}{c}{ Overshoot } \\
\hline Tak terkontrol & $2579.9 \mathrm{Rpm}$ & $3645.4 \mathrm{Rpm}$ \\
Terkontrol & $2628.3 \mathrm{Rpm}$ & - \\
\hline
\end{tabular}

\section{KESIMPULAN}

Kesimpulan dari perancangan sistem ini, bahwa cuk konverter digunakan sebagai menaikan dan menurunkan tegangan. Dari percobaan simulasi pada sistem cuk konverter tak terkontrol sering terjadi overshoot beberapa saat pada awal motor bekerja. Dari percobaan sistem terkontrol tidak terjadi overshoot karena dapat diredam oleh sistem PID sehingga tidak terjadi lonjakan kecepatan pada motor BLDC itu sendiri. Sedangngkan pada saat sistem tidak terkontrol ditunjukkan nilai overshoot pada saat tanpa beban sebesar 4148.1 Rpm, dan besar nilai overshoot berubah seiring dengan berubahnya beban yang diberikan. Saat beban sebesar $2.5 \mathrm{Nm}$ nilai overshoot sebesar $3901.2 \mathrm{Rpm}$ dan ketika beban sebesar $4.5 \mathrm{Nm}$ nilai overshoot menunjukkan angka $3645.4 \mathrm{Rpm}$. Hal ini membuktikan bahwa Cuk Konverter dapat digunakan untuk mengontrol kecepatan motor dan menekan laju overshoot.

\section{REFERENSI}

[1] Ardiansyah, M. D. \& Rohman, F., 2019. Implementasi dan Analisis Kendali Kecepatan Motor BLDC 1 kW Menggunakan Algoritma PID. Jurnal ELTEK, Oktober, XVII(02), pp. 81-93.

[2] Dodke, A., R.G.Shriwastava \& K.N.Sawalakhe, 2015. Design and Control of CUK Converter FED Brushless DC Motor Drive. Journal of Network Communications and Emerging Technologies, Volume $3(2)$.

[3] Mulyana, D., A, I. Y. \& AS, N. M., 2019. Pengaturan Kecepatan Motor Brushless DC menggunakan Cuk Konverter. Seminar Nasional Fortei Regional 7.

[4] Putra, H. P., Suryoatmojo, H. \& Anam, S., 2016. Perbaikan Faktor Daya Menggunakan Cuk Converter pada Pengaturan Kecepatan Motor Brushless DC. Jurnal Teknik ITS, Volume 5(2).

[5] Safii, M. I. et al., 2019. ANALISA PENGENDALIAN KECEPATAN MOTOR DC MENGGUNAKAN BUCK BOOST KONVERTER. Implementasi Hasil Riset Sumber Daya Laut dan Pesisir Dalam Peningkatan Daya Saing Indonesia, 11 Juli.

[6] Susanto, B. K., 2017. Desain dan Implementasi Konverter Cuk dengan Induktor Terkopel untuk Reduksi Ripple Arus Masukan. Surabaya: Institut Teknologi Sepuluh 
[7] Nopember Rosalina, Qosim, I. \& Mujirudin, M., 2017. Analiasa Pengaturan Kecepatan Motor DC Menggunakan Kontrol PID (Proportional Integral Derivative). Seminar Nasional TEKNOKA, Volume II, pp. 89-94.

[8] Wicaksono, H. \& Pramudijanto, J., 2004. Kontrol PID Untuk Pengaturan Kecepatan Motor DC Dengan Metode Tunning Direct Synthesis. Jurnal Teknik Elektro, IV(1), pp. 10-17.

[9] Wiriawan, A. R. J. \& Irawan, A., 2016. Pengaturan Kecepatan Motor DC dengan Kontrol Proporsional Integral Derifatif (PID) berbasis LabView. TELEKONTRAN, IV(2), pp. 13-23.

\section{BIOGRAFI PENULIS}

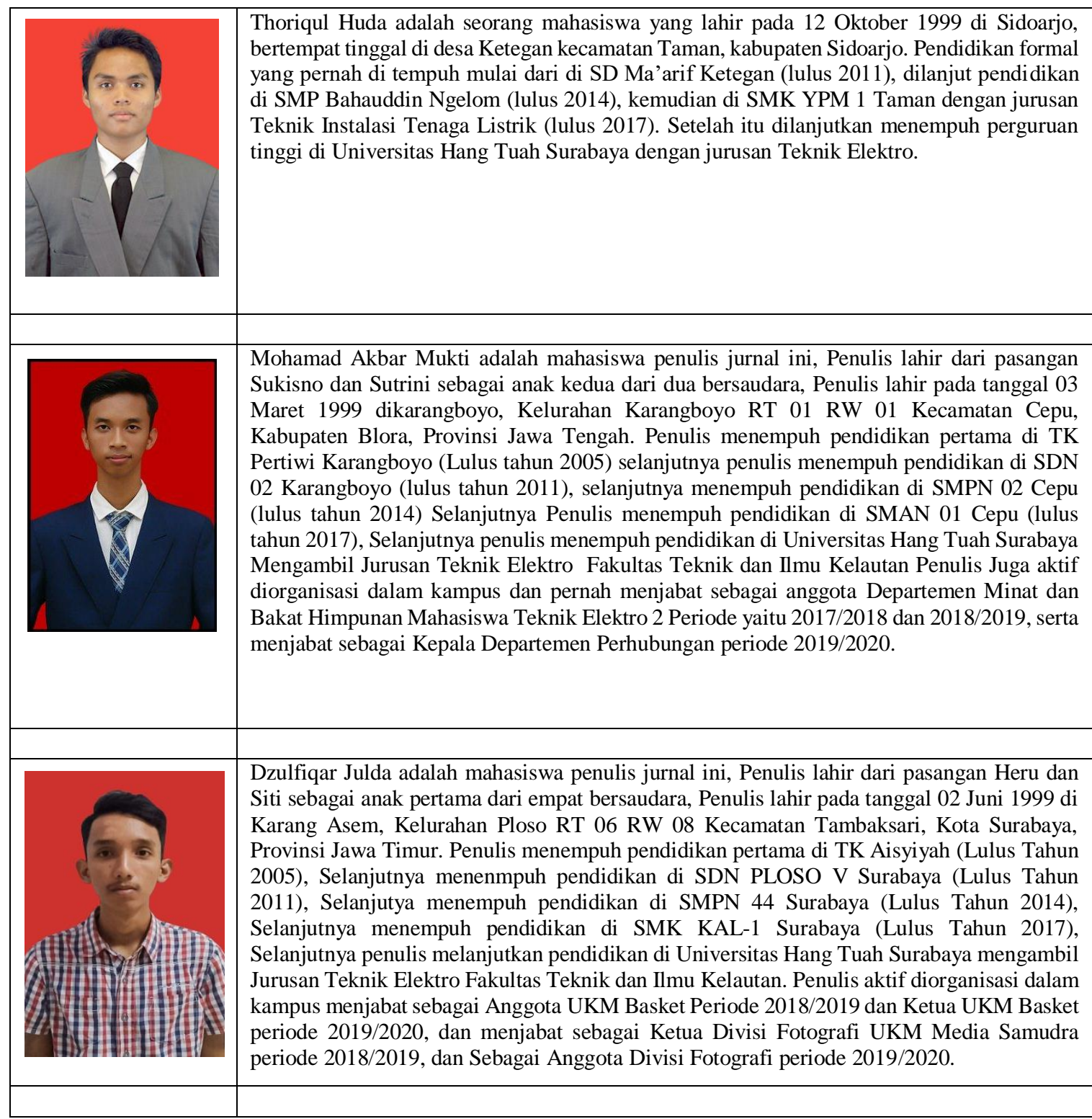




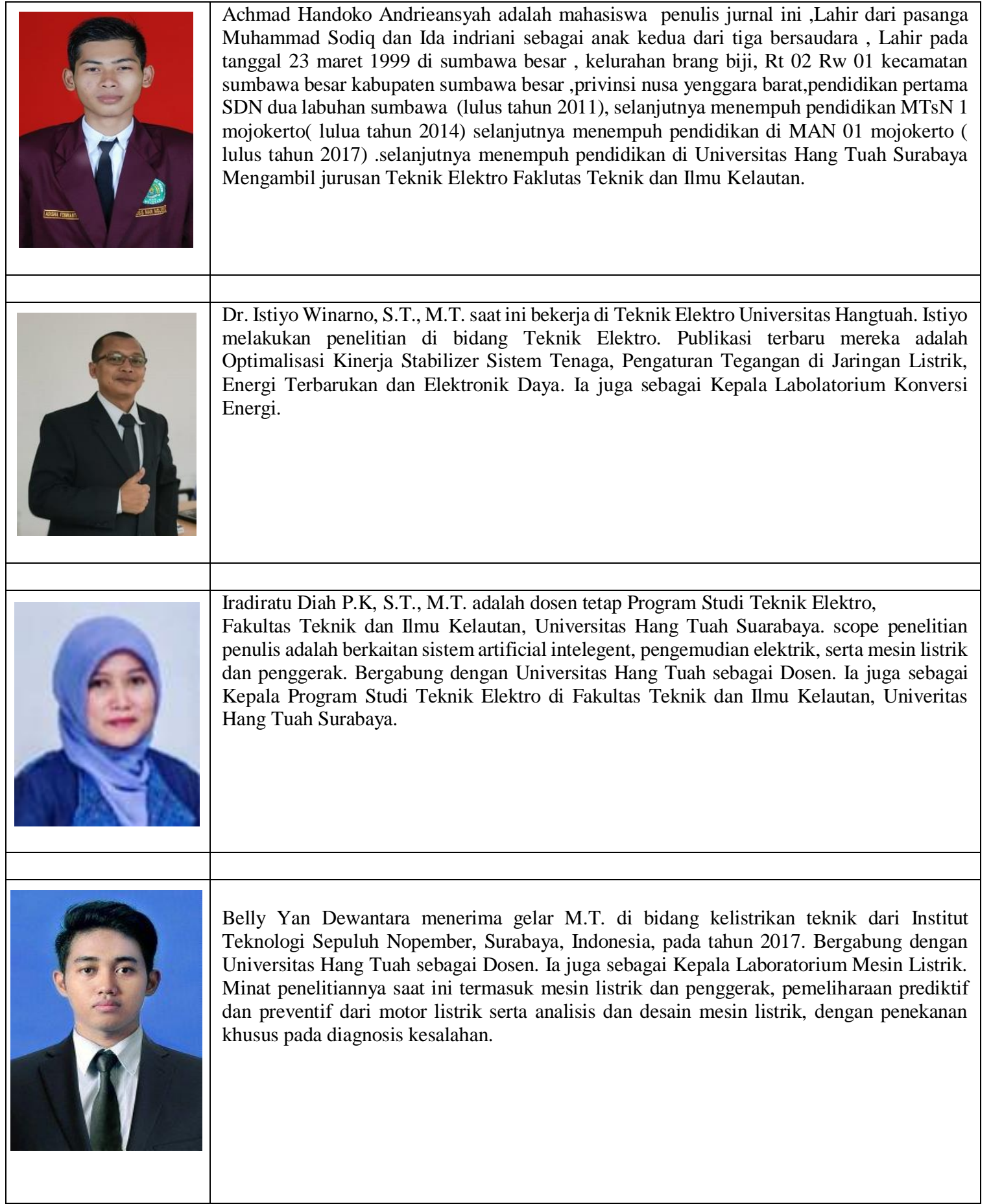

